\title{
IMPACT OF THE SATURATION CURRENT IS AND IDEALITY FACTOR N ON THE PERFORMANCE OF THE CHARACTERISTIC (I-V) OF A SOLAR CELL
}

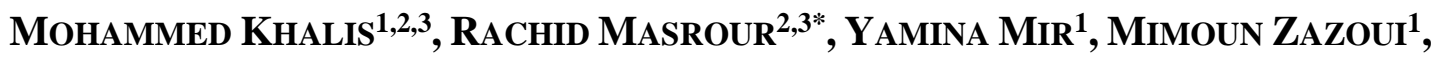 \\ ${ }^{1}$ Laboratory of Condensed Matter, Faculty of Sciences and Techniques, University of Hassan II \\ Mohammedia, Casablanca, Avenue Hassan II, BP 146, 28800 Mohammedia, Morocco \\ ${ }^{2}$ Laboratory of Materials, Processes, Environment and Quality, Cady Ayyed University, \\ National School of Applied Sciences, B.P. 63 46000, Safi, Morocco \\ ${ }^{3}$ Laboratory of Solid State Physics, Faculty of Science, Sidi Mohammed Ben Abdellah University, \\ Dhar Mahraz, BP 1796, Fez, Morocco \\ *Corresponding author: r.masrour@uca.ma
}

\begin{abstract}
The performance of a solar cell mainly is due to the quality of the starting material. During the production of the solar cell, several defects in different regions of the material appear. These defects degrade the efficiency of the solar cell. Thorough knowledge of the physical properties of defects requires highly sophisticated electrical current-voltage $(I-V)$ characterization techniques that provide information on the physical origin of the defects. The characteristic $(I-V)$ of the cell is governed by several parameters, such as the saturation current $I_{s}$ and the ideality factor $n$ which are the indicators of the quality of the solar cell. These parameters significantly reflect the existence of defects in the material. On the other hand, the use of such a characteristic to go back to the nature of the defects is not widespread because it lacks a data base between the main defects and the modification of the characteristic $(I-V)$. To extract the different parameters, we developed a method based on artificial neurons in Matlab code, then we applied this method to the following cells: GaAs, Simono and polycrystalline and CIGS thin-film cells by applying the model with two diodes. The results obtained demonstrate that the behavior of the ideality factor and the saturation current vary from one cell to another. This variance is important for polycrystalline Si and CIGS cells. Thus, this model is the most suitable for the diagnosis of the characteristics $(I-V)$ for $\mathrm{Si}$ and GaAs, but remains incoherent (Mismatches) to describe the characteristic of the CIGS cell because of the non-uniform presence of shunt defects which allowed us to add another component of the leakage current. Finally, this method correlates with the experimental characteristic $(I-V)$.
\end{abstract}

Key words: Dark and illumination current-voltage, Si, GaAs and CIGS, Current saturation and ideality factor, Defects and neural network method.

\section{INTRODUCTION}

In the single-diode model, the current $I_{S}$ represents the saturation current with the ideality factor $n$, whereas in the two-diode model of this current it has two components: the component $I_{S 1}$ which represents the diffusion saturation current due to the diffusion of the majority carriers of the most doped region towards the least doped region with an ideality fac- tor $\mathrm{n} 1$ and the component $I_{S 2}$ which corresponds to the recombination saturation current with the ideality factor $n_{2}$. On the other hand, the single-diode model or the five-parameter equivalent circuit $\left(I_{p h}\right.$, $I_{s}, R_{s}, R_{s h}$, and $n$ ) predicts accurately the performance of crystalline solar modules under various operating conditions (Cape \& Zehr, 1980; Araujo \& Sanchez, 1982; Charles et al., 1984; Ortiz et al., 2006; Salinger, 2006; Bouzidi et al., 2012; Khalis et al., 2011; 
Khalis et al., 2015; Khalis et al., 2016). This model is not valid for polycrystalline cells (Williams et al., 2015; Meyer, 2017; Hussein et al., 2001) which consist of small monocrystalline areas and are called grains. These grains are randomly oriented and interconnected by joints that create defects that can disrupt the crystal lattice. This circumstance can lead to a change in the conductivity nature, hence the need to use the two-diode model or the sevenparameter equivalent circuit $\left(I_{p h}, I_{s 1}, I_{s 2}, R_{s}, R_{s h}, n_{1}\right.$, $n 2)$ to describe the characteristic Experimental ( $I-V)$ (Bana \& Saini, 2016; Macabebe \& van Dyk, 2008; Galiana et al., 2008). The CIGS cell is also a polycrystalline cell and has grain boundaries that result in positively charged structural defects, mainly selenium gaps (Rau \& Schock, 1999). These charged defects locally cause a curvature of the bands (depletion zone) and can become a source of recombinations (William et al., 2011). However, the omnipresent method of quantifying the shunt, namely the measurement of a single parameter, the shunt resistance $\left(R_{s h}\right)$ does not make it possible to understand the type of shunt present. High leakage currents (or shunt) are detrimental to the fill factor (FF), allowing the surrounding (Williams et al., 2015) to add another component of the current to the twodiode model to adjust the characteristic $(I-V)$. In the literature several methods have been proposed for the extraction of these parameters, each of these methods has drawbacks either in terms of complexity of use and accuracy, or in terms of convergence and speed (Ortiz et al., 1999). Thus the least squares method is the simplest and fastest (Khalis et al., 2011; Khalis et al., 2015; Khalis et al., 2016) but it is unable to solve the problem with two diodes because it is based on Lambert $W$ function for the adjustment of the characteristic $(I-V)$. On the other hand, the ideality factor plays an important role regarding the performance of the photovoltaic system (da Luz et al., 2018) and organic-inorganic hybrid perovskite solar cells have attracted unprecedented attention in recent years due to their high power conversion efficiency, ease of fabrication and potential to yield low cost photovoltaic modules (Torabi et al., 2019). The effect of schottky junction formed between graphene and GaAs interface as well as the material properties on the performance of the device is demonstrated (Ansari et al., 2019).

In this work we will develop a method based on artificial neurons that takes into account both models to extract the five or seven previously described parameters from the experimental $(I-V)$ characteris- tic. We applied this method to the following cells: $\mathrm{Si}$-monoc and Si-polyc under illumination and GaAs and CIGS under darkness. There are two main tasks to accomplish according to this work. The first is to extract the parameters by applying the new method. The second is to analyze the effect of saturation current and the effect of ideality factor for the identification of certain defects in the studied material.

\section{MODEL OF A PV CELL}

There are several models that have been proposed to represent a PVC (PhotoVoltaic Cell). Among them, the diode model has been widely used thanks to its simplicity and precision suitable for most applications such as the performance analysis of a photovoltaic system (Soto et al., 2006; Kaushika \& Guatam, 2003), the sizing of a photovoltaic system (Li et al., 2009). The equivalent diagram of such a model is shown in figure 1.

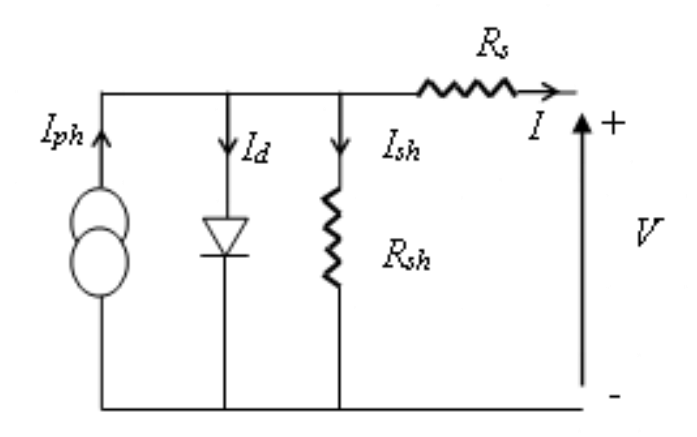

Fig. 1. Single diode Model.

The characteristic equation $(I-V)$ of this circuit is given by:

$$
\begin{aligned}
& I=I_{p h}-I_{d}-I_{s h} \\
& I=I_{p h}-I_{S}\left[\exp \left(\frac{V+I R_{S}}{n V_{T}}\right)-1\right]-I_{s h} \\
& I_{d}=I_{S}\left[\exp \left(\frac{V+I R_{S}}{n V_{T}}\right)-1\right]
\end{aligned}
$$

where: $V_{T}=k B T / q$ - the thermal voltage, $I$ - the output current, $V$ - the terminal voltage, $I_{p h}$ - the photocurrent, $I_{s}$ - the reverse saturation current, $R_{s}$ - the series resistance, $n$ - the ideality factor of the diode, $I_{s h}=\left(V-R_{s} I\right) / R_{s h}$ - the current term of leak, which is a function of the voltage, the series resistance $R_{s}$ and the shunt resistor $R_{s h}$.

Although this model brings some improvements, its accuracy remains debatable. To solve this problem, a two-diode model is introduced by considering 
two diodes connected in parallel with the current source, shown in figure 2 .

The current flowing through the first diode is the component of the diffusion current in the same manner as in the case of a single diode model while the current flowing through the second diode is the recombination current in the space charge region. This suggests that two terms of Shockley contribute to the saturation currents of a solar photovoltaic cell. The series and shunt resistors are identical to those defined for the single-diode model. The double diode model can be represented by the following equation (Ishaque et al., 2011):

$$
\begin{aligned}
& I=I_{p h}-I_{S 1}\left[\exp \left(\frac{V+I R_{S}}{n_{1} V_{T}}\right)-1\right] \\
& -I_{S 2}\left[\exp \left(\frac{V+I R_{S}}{n_{2} V_{T}}\right)-1\right]-I_{s h}
\end{aligned}
$$

where: $I_{s 1}, I_{s 2}$ - the saturation currents of the two diodes, $n_{1}, n_{2}$ - the corresponding ideality factors.

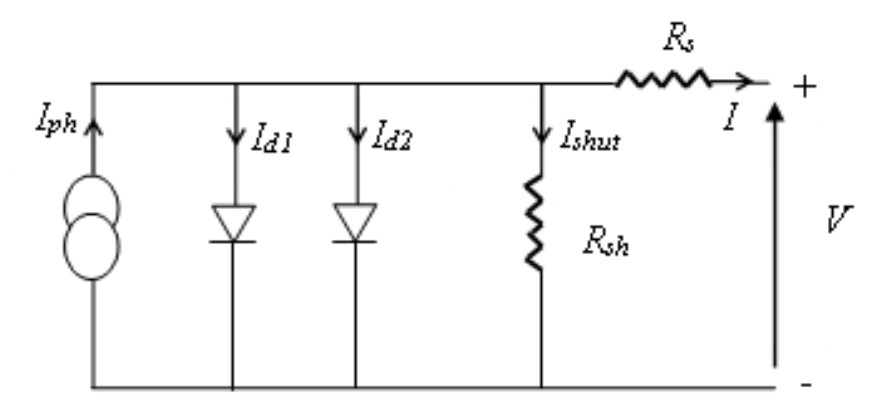

Fig. 2. Two-diode model.

Under the darkness, the equation of the characteristic for the model with two diodes is written as:

$$
\begin{aligned}
& I=I_{p h}-I_{S 1}\left[\exp \left(\frac{V-I R_{S}}{n_{1} V_{T}}\right)-1\right] \\
& -I_{S 2}\left[\exp \left(\frac{V-I R_{S}}{n_{2} V_{T}}\right)-1\right]+I_{s h}
\end{aligned}
$$

For heterojunction cells such as the CIGS cell, the two-diode model is insufficient to adjust the characteristic $(J V)$, which is why the authors (Williams et al., 2015) took into account another component of non-ohmic and non-linear leakage current in parallel, with the shunt resistor as shown in figure 3 .

This component corresponds to the last term of equation (4) which gives the relation between the current density $(\mathrm{J})$ and the voltage $(\mathrm{V})$ under the darkness of a CIGS PV cell as follows:

$$
\begin{aligned}
& J=J_{S 1}\left[\exp \left(\frac{V-J R_{S}}{n_{1} V_{T}}\right)-1\right] \\
& +J_{S 2}\left[\exp \left(\frac{V-J R_{S}}{n_{2} V_{T}}\right)-1\right]+J_{s h}+k\left(V-J R_{S}\right)^{m}
\end{aligned}
$$

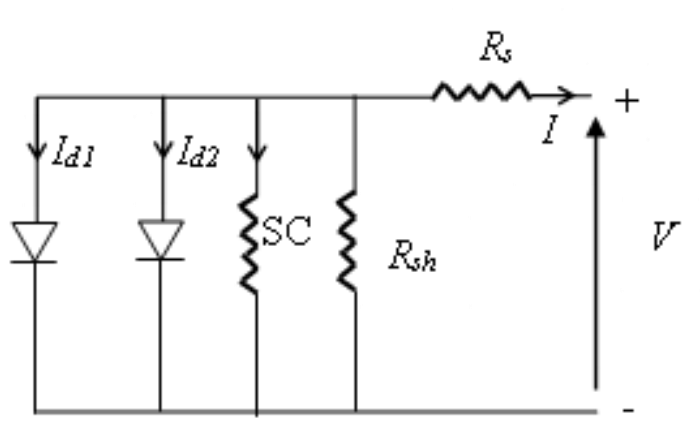

Fig. 3. Two-diode model with non-ohmic shunt current SC.

\section{RESULTS AND DISCUSSION}

The current and voltage measured are essential for the approach of our method to make the detection of defects. This modeling approach is validated by a series of experiments. It remains now to use the results of these simulations to develop a characterization of defects from the characteristic $(I-V)$ for diagnostic purposes. Figure 4 contains the measured and calculated current values and table.1, contains the values of the seven parameters obtained by executing the algorithm presented in this work.

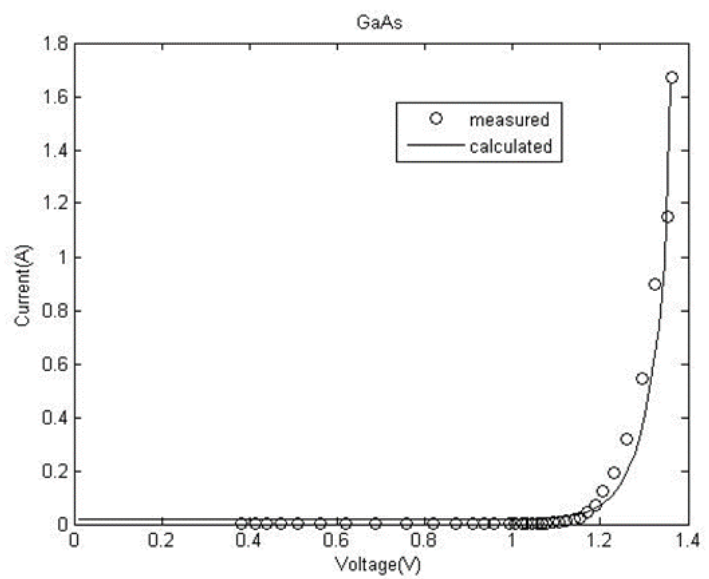

Fig. 4. Comparison of experimental and theoretical dark (I-V)curves with the two-diode model of the Solar Cell GaAs (Galiana et al., 2008).

We note from figure 4 that the measured values coincide with those calculated by the calculation codes made. The analysis of this table shows that $n_{1}$ $=1.15$ and $n_{2}=2.04$ remain very close to the ideal cases $n_{1}=1$ and $n_{2}=2$ and the series resistance $R_{s}=$ $61 \mathrm{~m} \Omega$ is very weak, these parameters do not pro- 
vide any contribution for the discrimination of defects. But it is found that the shunt resistance has decreased $R_{s h}=60 \Omega$ and the saturation current component $I_{s 2}=5.1 \times 10^{-9}$ A has increased, so it can be concluded that the faults are diagnosed at leakage current due to shunt resistance and faults out of the middle of the depletion zone.

Table 1. Data used for material description in numerical modeling.

\begin{tabular}{|c|c|c|}
\hline $\begin{array}{c}\text { Parameters } \\
\text { mc-si solar cell }\end{array}$ & $\begin{array}{c}\text { Experimental results } \\
\text { (Galiana et al., 2008) }\end{array}$ & $\begin{array}{c}\text { Our } \\
\text { method }\end{array}$ \\
\hline$R_{s h}, \Omega$ & 3000 & 60 \\
\hline$R_{s}, \mathrm{~m} \Omega$ & 70 & 61 \\
\hline$I_{s l}, \mathrm{~A}$ & $1.4 \times 10^{-21}$ & $1 \times 10^{-23}$ \\
\hline$I_{s 2}, \mathrm{~A}$ & $2.9 \times 10^{-12}$ & $5.1 \times 10^{-9}$ \\
\hline$n_{1}$ & 1 & 1.15 \\
\hline$n_{2}$ & 2 & 2.05 \\
\hline
\end{tabular}

With table 2, it can be concluded that the faulty discrimination capability remains invariant when switching from modeling to a diode to two-diode modeling. This is due to the crystalline perfection. Comparison of experimental and theoretical illumination IV-curves with the two-diode model of the Solar Cell monoc-Si is presented in figure 5 .

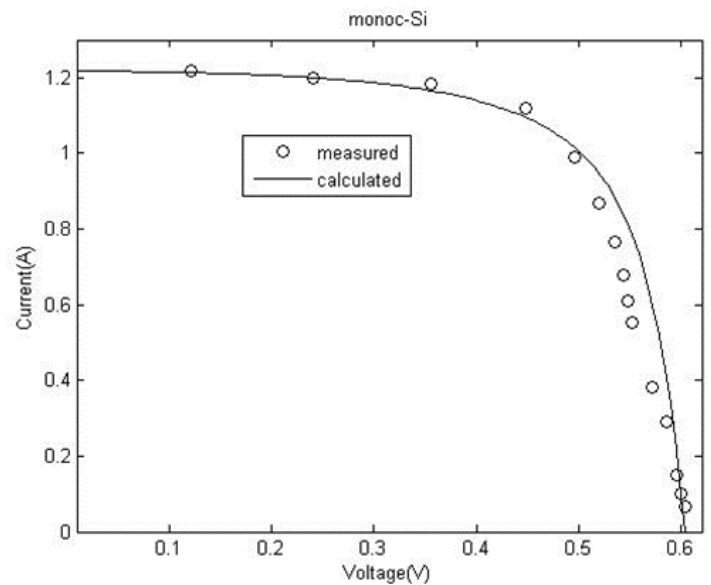

Fig. 5. Comparison of experimental and theoretical illumination $I V$-curves with the two-diode model of the Solar Cell monoc-Si (Khalis et al., 2016).

Table 2. Parameters obtained from the experimental data fit of figure 5 by the two-diode model solar cell monoc-Si.

\begin{tabular}{|c|c|c|}
\hline $\begin{array}{c}\text { Parameters } \\
\text { monoc-si solar } \\
\text { cell }\end{array}$ & $\begin{array}{c}\text { MLS extracted pa- } \\
\text { rameters values sin- } \\
\text { gle-diode (Khalis et } \\
\text { al., 2016) }\end{array}$ & $\begin{array}{c}\text { Extracted } \\
\text { parameters } \\
\text { values two- } \\
\text { diode }\end{array}$ \\
\hline$R_{s h}, \Omega$ & 20.5 & 4.45 \\
\hline$R_{s}, \mathrm{~m} \Omega$ & 54 & 11 \\
\hline$I_{s 1}, \mathrm{~A}$ & $4.78 \times 10^{-8}$ & $1 \times 10^{-16}$ \\
\hline$I_{s 2}, \mathrm{~A}$ & - & $1 \times 10^{-5}$ \\
\hline$I_{p h}, \mathrm{~A}$ & 1.221 & 1.22 \\
\hline$n_{1}$ & 1.375 & 1.14 \\
\hline$n_{2}$ & - & 2.04 \\
\hline
\end{tabular}

In general, the saturation current is given by the following formula:

$I_{S}=\left(\frac{e D_{h}}{L_{h} N_{d}}+\frac{e D_{e}}{L_{e} N_{a}}\right) n_{i}^{2} A$

where: $n_{i}=10^{10} \mathrm{~cm}^{-3}$ - the intrinsic concentration, $D_{e}$ $=10^{2} \mathrm{~cm}^{2} \mathrm{~s}^{-1}$ - the diffusion coefficient, $L_{e}=1 \mu \mathrm{m}$ the diffusion length, $N_{a}=10^{16} \mathrm{~cm}^{-3}$ - the concentration acceptors, $N_{d}=10^{16} \mathrm{~cm}^{-3}$ - the concentration donors, $\left(N_{a}<<N_{d}\right)$.

Applying formula (5) to our monocrystalline silicon cell (Khalis, et al., 2016), the saturation current can be calculated for the monocrystalline silicon cell (Khalis et al., 2016):

$$
\begin{aligned}
& I_{S}=\frac{e D_{e}}{L_{e} N_{a}} n_{i}^{2} \mathrm{~A} \\
& =38.44 \frac{1.6 \times 10^{-19} \times 10^{-2} \times 10^{20}}{10^{-3} \times 10^{16}}=6.15 \times 10^{-13} \mathrm{~A}
\end{aligned}
$$

This value is much lower than the value found experimentally $I_{s 2}=1 \times 10^{-5} \mathrm{~A}$ for the two-diode model, but close to the value found experimentally $I_{s 1}=1 \times 10^{-16} \mathrm{~A}$ for the two diode model.

The reverse current component due to thermal generation electron-houle pairs within the depletion region is given by;

$I_{S 2}=\frac{e W n_{i}}{\tau_{g}} \quad \mathrm{~A}$

This value is greater than the value of the saturation current found experimentally $I_{s 1}=1 \times 10^{-16} \mathrm{~A}$ by the two-diode model but remains lower than experimentally found $I_{s 2}=1 \times 10^{-5}$ A by the two-diode model. So there is another recombination current that appears in the cell either in volume or on the surface.

The trap states that were presumed to be exactly in the middle of the forbidden band do not appear there in reality. In addition, the interface and the surface recombination were not taken into account in the derivation. These simplifications are the main causes of the deviation since $I_{s 2} \gg I_{s 1}$. This reflects the fact that the operation of the cell implements a recombination current, which actually predominates the diffusion current. Comparison of experimental and theoretical illumination IV-curves with the twodiode model of the Solar Cell polyc-Si is presented in figure 6. Parameters obtained from the experimental data fit of this figure by the two-diode model 
solar cell polyc-Si are given in table 3 and by the two-diode model solar cell polyc-Si in table 4.

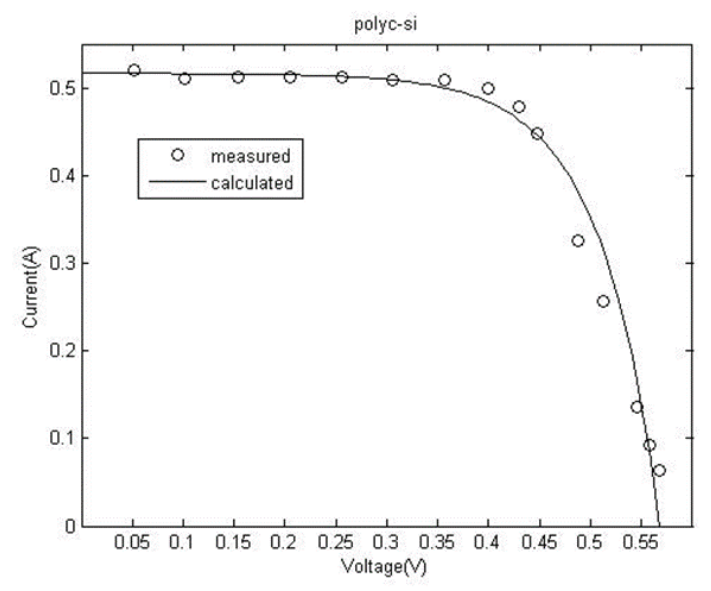

Fig. 6. Comparison of experimental and theoretical illumination $I V$-curves with the two-diode model of the Solar Cell polyc-Si (Khalis et al., 2016)

Table 3. Parameters obtained from the experimental data fit of figure 6 by the two-diode model solar cell polyc-Si (Khalis et al., 2016).

\begin{tabular}{|c|c|c|}
\hline $\begin{array}{c}\text { Parameters } \\
\text { polyc-si solar } \\
\text { cell }\end{array}$ & $\begin{array}{c}\text { MLS extracted pa- } \\
\text { rameters values sin- } \\
\text { gle-diode (Khalis et } \\
\text { al., 2016) }\end{array}$ & $\begin{array}{c}\text { Method: Ex- } \\
\text { tracted parame- } \\
\text { ters values } \\
\text { two-diode }\end{array}$ \\
\hline$R_{s h}, \Omega$ & 125 & 200 \\
\hline$R_{s}, \mathrm{~m} \Omega$ & 164 & 82 \\
\hline$I_{s l}, \mathrm{~A}$ & $2.95 \times 10^{-8}$ & $1.35 \times 10^{-10}$ \\
\hline$I_{s 2}, \mathrm{~A}$ & - & $4 \times 10^{-5}$ \\
\hline$I_{p h}, \mathrm{~A}$ & 0.517 & 0.5167 \\
\hline$n_{1}$ & 1.339 & 1.113 \\
\hline$n_{2}$ & - & 2.334 \\
\hline
\end{tabular}

Table 4. Parameters obtained from the experimental data fit of figure 6 by the two-diode model solar cell polyc-Si.

\begin{tabular}{|c|c|c|}
\hline $\begin{array}{c}\text { Parameters } \\
\text { monoc-si solar } \\
\text { cell }\end{array}$ & $\begin{array}{c}\text { MLS extracted pa- } \\
\text { rameters values sin- } \\
\text { gle-diode (Khalis et } \\
\text { al., 2016) }\end{array}$ & $\begin{array}{c}\text { Method: Ex- } \\
\text { tracted parame- } \\
\text { ters values } \\
\text { two-diode }\end{array}$ \\
\hline$R_{s h}, \Omega$ & 20.5 & 4.45 \\
\hline$R_{s}, \mathrm{~m} \Omega$ & 54 & 11 \\
\hline$I_{s l}, \mathrm{~A}$ & $4.78 \times 10^{-8}$ & $1 \times 10^{-16}$ \\
\hline$I_{s 2}, \mathrm{~A}$ & - & $1 \times 10^{-5}$ \\
\hline$I_{p h}, \mathrm{~A}$ & 1.221 & 1.22 \\
\hline$n_{1}$ & 1.375 & 1.14 \\
\hline$n_{2}$ & - & 2.04 \\
\hline
\end{tabular}

The defects caused by the increase of the resistance of the elements in series (resistance of the cells, resistance of the connectors). The defects caused by the decrease of a resistance in parallel (parallel resistance of the cells) during the transition from the model to a diode to the diode model are decreasing. The defects caused by the saturation current $I_{s 1}=1.35 \times 10^{-10} \mathrm{~A}$ are increased relative to the saturation current $I_{s 1}=1.35 \times 10^{-16} \mathrm{~A}$ of the monocrystalline silicon cell, and the factor of ideality $n_{2}=2.334$ away from the ideality factor $n_{2}=2$. For this purpose, the saturation current of the polycrystalline cell is calculated as:

$$
\begin{aligned}
& I_{S_{1}}=\frac{e D_{e} n_{i}^{2}}{L_{e} N_{a}} \mathrm{~A} \\
& =19.76 \frac{1.6 \times 10^{-19} \times 10^{-2} \times 10^{20}}{10^{-3} \times 10^{16}}=3.16 \times 10^{-13} \mathrm{~A}
\end{aligned}
$$

This value is much lower than the value found experimentally $I_{s 1}=1.35 \times 10^{-10} \mathrm{~A}$ for the two-diode model and $n_{1}=1.113$, which is close to the theoretically assumed value $(n=1)$, that is to say that a normal broadcast process takes place. However, there was a deviation concerning the ideality factor $n_{2}=2.334$, hence the need for the two-diode model to discriminate defects in the polycrystalline cell.

The reverse current component due to thermal generation electron-hole pairs within the depletion region is given by:

$$
\begin{aligned}
& I_{S_{1}}=\frac{e W n_{i}}{\tau_{g}} \mathrm{~A} \\
& =19.76 \frac{1.6 \times 10^{-19} \times 10^{-2} \times 10^{20}}{10^{-3} \times 10^{16}}=3.16 \times 10^{-10} \mathrm{~A}
\end{aligned}
$$

This value is very close to Is 1 but much less than $I_{s 2}=4 \times 10^{-5} \mathrm{~A}$ found experimentally. This reflects the fact that the operation of the cell implements a diffusion current and a recombination current, with no real predominance of any of these two terms in the field of illumination and at the temperature considered. The two-exponential model is therefore the most appropriate for considering an accurate simulation of the polycrystalline silicon cell in real-life situations.

Figure 7 shows the comparison between the calculated curves and the measurement curves, and the coincidence of the two curves is very good. Table 4 shows that the values found by our method are in good agreement with those found by the authors (Williams et al., 2015) and the failure of the twodiode modeling of the PV CIGS cell to obtain the characteristic $(I-V)$ since $k=9.2 \mathrm{~A} / \mathrm{Vm}$ with $m=2.4$ hence the need for the non-ohmic shunt current component. From the results, we note that there is an important influence on the factors of ideality of the cell with $n_{1}=1.4$ very far from the ideal state of the cell $n_{1}=1$ and the value $n_{2}=6.5>2$ shows that the 
recombination centers are not localized in the middle of the forbidden band, but have variable positions in the volume and in the interface of the cell. This second diode ideality value for the CIGS solar cell is higher, indicating that the main recombination mechanism is more closely related to the recombination at the interface than to the recombination in the depletion region. Increasing the saturation current density $J_{s 2}=9.3 \times 10^{3} \mathrm{~mA} \cdot \mathrm{cm}^{-2}$ could be due to increased defect density in the CIGS absorber layer. To get a correlation between the experimental results and the simulations, we also introduced a component of the non-ohmic current due to the variation of the volumetric flaw density to allow a better fit $(k=9.2$ $\mathrm{A} / \mathrm{Vm}, m=2.4$ ).

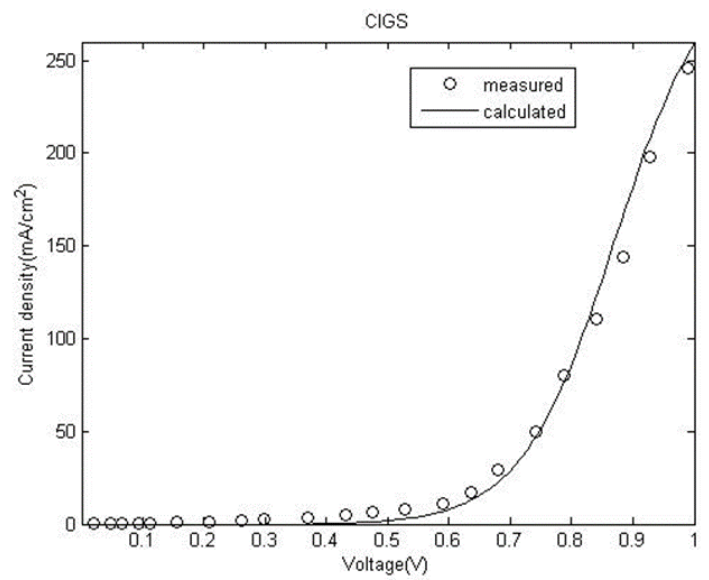

Fig. 7. Comparison of experimental and theoretical dark $I V$ curves with the two-diode model of the Solar Cell CIGS (Williams et al., 2015).

Table 5 summarizes the parameters $\left(n\right.$ and $I_{S}$ ) obtained from the adjustment by our method. These values were confirmed by measurements $(I-V)$ in the dark and under illumination. The closer $n_{1}$ is to the unit or $n_{2}$ is close to 2, the quality of the cell is better. Moreover, $n_{1}>1$ implies that, apart from the ideal recombination in the quasi-neutral $p$ and $n$ regions, non-ideal recombination also takes place in the space charge region (SCR) of the $p$-n junction (Lorenzo, 1994). The relatively high ideality factor $n_{2}>2$ for polyc-Si and CIGS cells reveals that their cell quality is lower than that of GaAs and monoc-Si cells. It also implies that non-ideal recombination takes place in particular for polyc-Si and CIGS cells. The increase in the ideality factor for the polyc-Si cell involves an increase in the saturation current Is 1 and recombination current $I_{s 2}$. This increase is due to the grains of the joints which cause the formation of the defects which in turn improve the recombination and subsequently the deterioration of the performance and the quality of the cell. The high value of
$I_{s 2}$ and $n_{2}$ for the CIGS cell is mainly due to less rigorous manufacturing processes.

Table 5. Parameters ( $\left.n, I_{S}\right)$ obtained for various solar cells technologies from (I-V) measurements.

\begin{tabular}{|c|c|c|c|c|}
\hline Solar cell & GaAs & Monoc-Si & Polyc-Si & \\
\hline$n_{1}$ & 1.15 & 1.14 & 1.113 & 1.4 \\
\hline$n_{2}$ & 2.05 & 2.04 & 2.334 & 6.5 \\
\hline$I_{s 1}, \mathrm{~A}$ & $1 \times 10^{-23}$ & $1 \times 10^{-16}$ & $1.35 \times 10^{-10}$ & $2 \times 10^{-7}$ \\
\hline$I_{s 2}, \mathrm{~A}$ & $5.1 \times 10^{-9}$ & $1 \times 10^{-5}$ & $4 \times 10^{-5}$ & $9.3 \times 10^{-3}$ \\
\hline
\end{tabular}

\section{CONCLUSIONS}

The solar cells were characterized by the characteristic $(I V)$, a very good correlation was obtained between the parameters of the solar cell $\left(I_{p h}, I_{s 1}, I_{s 2}\right.$, $\left.R_{s}, R_{s h}, n_{1}, n_{2}\right)$ simulated by our method and the experimental results. As expected, the saturation current and the ideality factor increase as one goes from a monocrystalline structure to a polycrystalline structure. However, the other parameters of the cell $\left(n_{1}, R_{s}, R_{s h}\right)$ vary little and remain in a normal operating process of the cell. The analysis of the diode parameters of the mono- $\mathrm{Si}$ and GaAS solar cell devices studied indicates that $\mathrm{n} 1$ is close to the ideal case $n=1$, i.e. a normal diffusion process takes place and $n_{2}$ is itself even very close to the theoretical case $n=2$, so a normal recombination process in the middle of the forbidden band occurs, but the increase of the $I_{s 2}$ recombination current shows that the trap states that were assumed to be exactly in the middle of the band gap do not appear there in reality, so a recombination current at the interface or volume of the cell takes place. Similarly, the analysis of the parameters of the polyc-Si and CIGS cells indicates a high ideality factor and a high value of the saturation current. This implies the existence of defects in volume and surface. Finally, for the CIGS cell, to have a correlation between the simulation by our method and the experimental results, we have introduced a term that takes into account the non-ohmic current. Comparing extracted device parameters with simulated values suggests that the two-diode model is more suitable than the one-diode model for describing the behavior of the $(I-V)$ curve. The twodiode model also provides more information needed to explain the mechanisms governing the curve $(I-V)$ in the dark.

\section{REFERENCES}

Ansari, Z.-A., Singh, T.J., Islam, S.M., Singh, S., Mahala, P., Khan, A., Singh, K.J., 2019, Photovoltaic solar cells based on graphene/gallium arsenideSchottky junction, Optik - International Journal for Light and Electron Optics, 182, 500-506. 
Araujo, G-L., Sanchez, E., 1982, Analytical expression for the determination of the maximum power point and the fill factor of a solar cell, Analytical expressions for the determination of the maximum power point and the fill factor of a solar cell, Solar Cells, 5, 377-386.

Bana, S., Saini, R.P., 2016, A mathematical modeling framework to evaluate the performance of single diode and double diode based SPV systems, Energy Reports, 2, 171-187.

Bouzidi, K., Chegaar, M., Aillerie, M., 2012, Solar cells parameters evaluation from dark I-V characteristics, Energy Procedia, 18, 1601-1610.

Cape, J-A., Zehr, S-W., 1980, Effect of temperature variation in concentrator cell series resistance measurement, Proc. $14^{\text {th }}$ Photovoltaic Specialists Conf., IEEE, New York, San Diego, 449-452.

Charles, J-P., Mekkaoui-Alaoui, I., Bordure, G., Mialhe, P., 1984, Etude comparative des modèles à une et deux exponentielles en vue d'une simulation précise des photopiles, Revue de Physique Appliquée, 19, 851-857.

Galiana, B., Algora, C., Rey-Stolle, I., 2008, Explanation for the dark I-V curve of III-V concentrator solar cells, Progress in Photovoltaics, 16, 331-338.

Hussein, R., Borchert, D., Grabosch, G., Fahrner, W.R., 2001, Dark I-V-T measurements and characteristics of (n) a$\mathrm{Si} /(\mathrm{p})$ c- Si heterojunction solar cells, Solar Energy Materials and Solar Cells, 69, 123-129.

Ishaque, K., Salam, Z., Taheri, H., Simple, 2011, Fast and accurate two-diode model for photovoltaic modules, Solar Energy Materials and Solar Cells, 95, 586-594.

Kaushika, N.D., Gautam, N.K., 2003, Energy yield simulations of interconnected solar PV arrays, IEEE Transactions on Energy Conversion, 18, 127-134.

Khalis, M., Masrour, R., Khrypunov, G., Kirichenko, M., Kudiy, D., Zazoui, M., 2016, Effects of Temperature and concentration mono and polycrystalline silicon solar cells: extraction parameters, Journal of Physics Conference Series, $758,1-10$.

Khalis, M., Masrour, R., Mir, Y., Zazoui, M., 2015, Two methods for extracting the parameters of a nonideal diode, $I n$ ternational Journal of Physical Sciences, 10, 270-275.

Khalis, M., Mir, Y., Hemine, J., Zazoui, M., 2011, Extraction of equivalent circuit parameters of solar cell: influence of temperature, The European Physical Journal Applied Physics, 54, 1-6.

Li, C.-H., Zhu, X.-J., Cao, G.-Y., Sui, S., Hu, M.-R., 2009, Dynamic modeling and sizing optimization of stand-alone photovoltaic power systems using hybrid energy storage technology, Renewable Energy, 34, 815-826.

Lorenzo, E., 1994, Solar electricity: engineering of photovoltaic systems, ed., Davies, P., Sevilla, Progensa.

Macabebe, E.Q.B., van Dyk, E.E., 2008, Parameter extraction from dark current-voltage characteristics of solar cells, $R e$ search Letters, South African Journal of Science, 104, 401404.

Meyer, E-L., 2017, Extraction of saturation current and ideality factor from measuring Voc and Isc of photovoltaic modules, International Journal of Photoenergy, doi.org/ $10.1155 / 2017 / 8479487$.

Rau, U., Schock, H.W., 1999, Electronic properties of $\mathrm{Cu}$ (In, Ga)Se2 heterojunction solar cells-recent achievements, current understanding, and future challenges, Applied Physics A: Materials Science \& Processing, 69, 131-147.

Salinger, J., 2006, Measurement of solar cell parameters with dark forward I-V characteristics, Acta Polytechnica, 46, 25-27.

Soto, W-D., Klein S-A., Beckman, W-A., 2006, Improvement and validation of a model for photovoltaic array performance, Solar Energy, 80, 78-88.

Torabi, N., Behjat, A., Zhou, Y., Docampo, P., Stoddard, R,J., Hugh, W,H., Tayebeh, A., 2019, Progress and challenges in perovskite photovoltaics from single- to multi-junction cells, Materials Today Energy, 12, 70-94.

William, N-S., Siebentritt, S., Stolt, L., 2011, in: Handbook of Photovoltaic Science and Engineering, 546-599.

Williams, B.,L., Smit, S., Kniknie, S.B.J., Bakker, K.J., Keuning, W., Kessels, W.M.M., Schropp R.E.I., Creatore, M., 2015, Identifying parasitic current pathways in CIGS solar cells by modelling dark $\mathrm{J}-\mathrm{V}$ response, Progress in Photovoltaics, 23, 1516-1525.

\section{WPLYW PRADU NASYCENIA IS I WSPÓŁCZYNNIKA DOSKONAŁOŚCI ZLĄCZA n NA CHARAKTERYSTYKE (I-V) OGNIWA SŁONECZNEGO}

\section{Streszczenie}

Zachowanie się ogniw słonecznych zależy w dużej mierze od jakości materiału. W procesie wytwarzania baterii może pojawić się szereg wad w różnych jej częściach. Te wady obniżają wydajność ogniwa. Dokładna analiza właściwości fizycznych wad wymaga dokładnego określenia charakterystyki prądowonapięciowej $(I-V)$, która dostarczyłaby informacji o przyczynie tych wad. Charakterystyka prądowo-napięciowa $(I-V)$ baterii zależy od szeregu parametrów takich jak prąd nasycenia $I_{s}$, i współczynnik doskonałości złącza $n$, które sa wskaźnikami jakości baterii. Te parametry dobrze odzwierciedlają istnienie wad w materiale. $\mathrm{Z}$ drugiej strony, ze względu na brak danych dotyczących korelacji między głównymi wadami i zmianami charakterystyk (IV), wykorzystanie tych charakterystyk do określenia natury powstałych wad nie jest rozpowszechnione. Aby rozróżnić wpływ różnych parametrów opracowano metodę wykorzystującą sztuczną sieć neuronową i oprograowanie MatLab. Tę metodę zastosowano do następujących ogniw słonechnych: GaAs, Si-mono and polikrystaliczny oraz cienkie warstwy CIGS popraz zaqstosowanie modelu $\mathrm{z}$ dwoma diodami. Uzyskane wyniki wykazały, że zachowanie się współczynnika doskonałości złącza i prądu nasycenia zmienia się dla różnych ogniw. Te różnice są ważne zarówno dla ogniw Si jak i CIGS. Stąd opracowany model jest najbardziej przydatny do diagnozowania charakterystyk $(I-V)$ dla ogniw $\mathrm{Si}$ i GaAs, ale jest niespójny przy opisie ogniw CIGS, ponieważ występują w nich w sposób nierównomierny wady powodujące zwarcie elektrod. To pozwoliło Autorom dodać prąd upływu, jako dodatkowy parameter modelu. W artykule potwierdzono zgodność opracowanej metody z doświadczalnymi charakterystykami $(I-V)$.

Received: March 11, 2019 Received in a revised form: September 4, 2019. Accepted: October 19, 2019. 